Zeitschrift für

Rheumatologie

Tight Junctions

5. rheumatologisches/dermatologisches Forschungssymposium

Leipzig, 08.-09. November 2013

Indexed in Science Citation Index Expanded and Medline
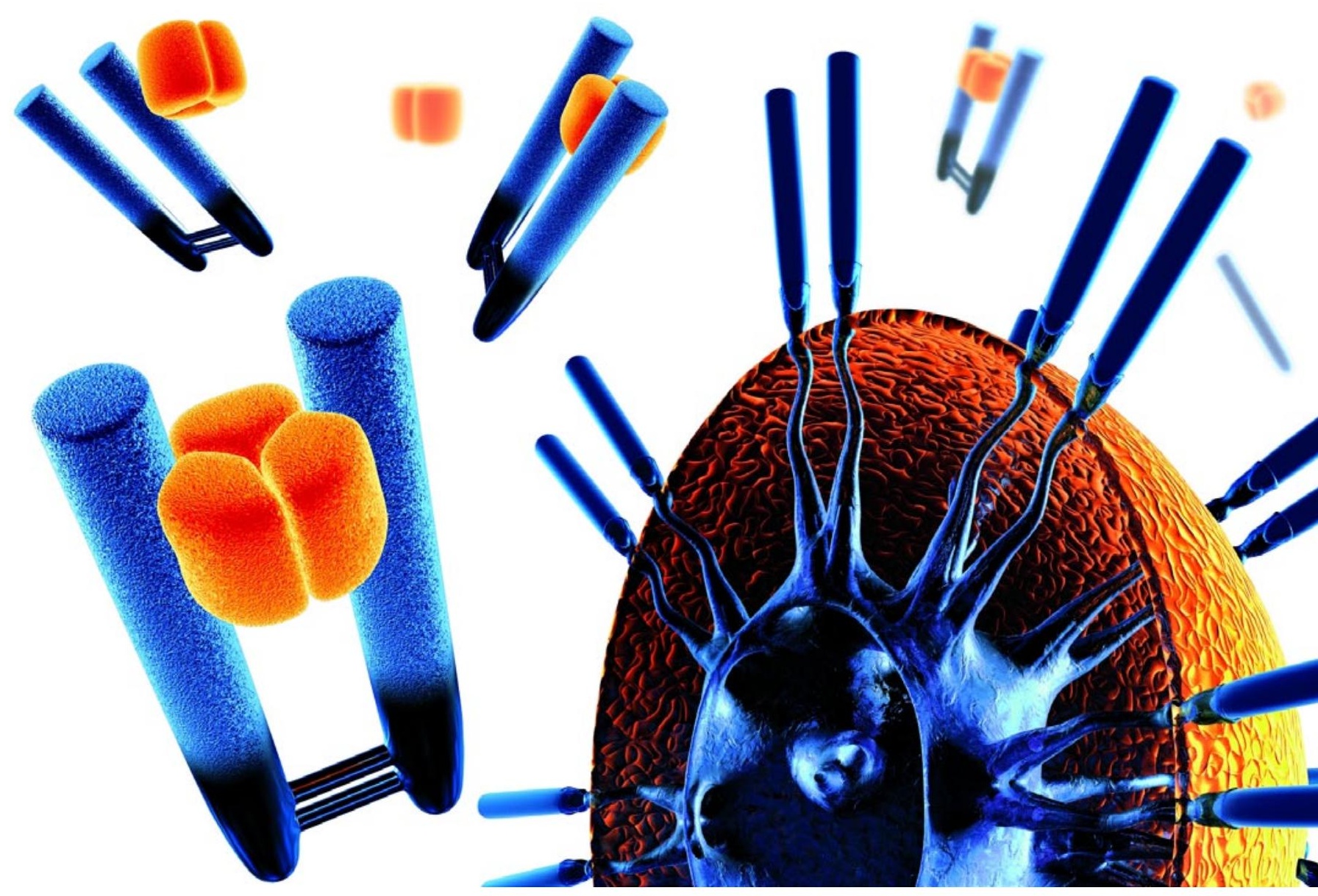

www.ZeitschriftfuerRheumatologie.de

焦 Springer Medizin 



\section{Tight Junctions}

\section{5. rheumatologisches/dermatologisches Forschungssymposium}

Leipzig, 08.-09. November 2013

\section{Abstracts}

Guest Editors Supplement

Prof. Dr. Christoph Baerwald, Leipzig

Prof. Dr. Ulf Müller-Ladner, Bad Nauheim

Prof. Dr. Thomas Schwarz, Kiel

This supplement is kindly supported by Pfizer Pharma GmbH, Berlin 


\section{Content}

1. Answers to clinical questions. . . . . . . . 5

2. From nano to macro ........... 6

3. Clinical studies. . . . . . . . . . . . 8

4. Prognosis and outcome . . . . . . . . 10

5. Abstracts without presentation . . . . . 13

Authors ................ 14 .

13

\section{Impressum}

Eigentümer \& Copyright $\odot$ Springer-Verlag Berlin Heidelberg 2013, Springer Medizin c/o Springer-Verlag GmbH, Tiergartenstr. 17, 69121 Heidelberg Tel. +49 6221/487-0, www.springer.de

Springer Medizin ist Teil der Fachverlagsgruppe Springer Science+Business Media Geschäftsführung Springer Medizin: Harm van Maanen (Executive Vice President), Fabian Kaufmann, Dr. Esther Wieland, Matthias Wissel

Director Journals \& ePublishing: Dr. Paul Herrmann (v.i.S.d.P.)

Leitung Fachzeitschriften: Monika Kretz

Director Editorial Processes: Dr. Frank Sommerauer

Redaktionsleitung „Zeitschrift für Rheumatologie“:

Michal Bänfer, Tel. -8218, Fax -68218, michal.baenfer@springer.com

Leitung Copy-Editing/Lektorat: Sabine Hofmann, Tel. -8468, sabine.hofmann@springer.com

Technische Redaktion: Jaroslaw Sydor, Tel. -8244, Fax -68244,

jaroslaw.sydor@springer.com

Leitung Herstellung: Alison Hepper, alison.hepper@springer.com

Chef vom Dienst/Herstellung: Jutta Daum, jutta.daum@springer.com

Gesamtleitung Sales \& Marketing: Fabian Kaufmann

Anzeigen: Jens Dessin (Leitung Sales \& Advertising);

Noëla Krischer-Janka (Anzeigenleitung, verantwortlich), Noela.Krischer@springer.com,

Tel. +49 30/82787-5731, www.mediadaten.springermedizin.de

Gesamtleitung Corporate Publishing: Ulrike Hafner

Druck: Stürtz GmbH, Alfred-Nobel-Str. 33, 97080 Würzburg. Printed in Germany

Erscheinungsweise: 10-mal jährlich

Papierausgabe: ISSN 0340-1855, gedruckt auf säurefreiem Papier.

Elektr. Ausgabe: ISSN 1435-1250

Die elektronische Version finden Sie unter www.zeitschriftfuerrheumatologie.de.

Die Formulierung der Beitragsinhalte können zwischen Online- und Druckausgabe gering-

fügig voneinander abweichen.

Bezugspreise: Vorzugspreis für persönliche Abonnenten inkl. Online-Basis-Lizenz 2013: EUR 245,- (unverb. Preisempfehlung inkl. 7\% deutscher MwSt. und Versandkosten). Vorzugspreis für Ärzte in Aus- und Weiterbildung und Studenten inkI. Online-BasisLizenz 2013: EUR 147,00 (unverb. Preisempfehlung inkl. 7\% deutscher MwSt.) zzgl. Versandkosten.

Institutspreis inkl. Online- Basis-Lizenz 2013: EUR 1.200,54 (unverb. Preisempfehlung inkl. 7\% deutscher MwSt.) zzgl. Versandkosten (Deutschland: EUR 25,-, Ausland: EUR 40,-). Einzelheftpreis 2013: Euro 36,- (unverb. Preisempfehlung inkl. 7\% deutscher MwSt.) zzgl. Versandkosten. Der Bezugspreis ist im Voraus zu zahlen. Das Abonnement kann bis 30 Tage vor Ende des Bezugszeitraums gekündigt werden.

Bestellungen oder Rückfragen nimmt jede Buchhandlung oder der Verlag entgegen. Springer Customer Service Center GmbH, Haberstr. 7, 69126 Heidelberg,

Tel. +49 62 21-345-4303, Fax +49 62 21-345-4229, Leserservice@springer.com (Mo.-Fr. $8.00 \mathrm{Uhr}$ bis $18.00 \mathrm{Uhr}$ )

Kontakt
Haben Sie Fragen, Anmerkungen,
Lob oder Kritik?
So erreichen Sie den Verlag:
Fragen zum Abonnement/Adressänderungen/Online-Zugang
Springer Customer Service Center GmbH
Haberstraße 7,69126 Heidelberg
Tel.: +49 (0)6221/345-4303, Fax: +49 (0)6221/345-4229,
Montag bis Freitag, 8.00 Uhr bis 18.00 Uhr
E-Mail: Leserservice@springer.com
Wichtiger Hinweis: Zeitschriften werden nicht automatisch im Rahmen
eines Nachsendeantrags berücksichtigt. Bitte informieren Sie unseren
Kundenservice daher frühzeitig über Adressänderungen.
Verlagsredaktion Springer Medizin
Michal Bänfer
Springer-Verlag GmbH, Tiergartenstr. 17, 69121 Heidelberg,
Tel.: +49 (0)6221/487-8218, E-Mail: michal.baenfer@springer.com

Copyright \& allgemeine Hinweise: Mit der Annahme eines Beitrags zur Veröffentlichung erwirbt der Verlag vom Autor alle Nutzungsrechte, insbesondere das Recht der weiteren Vervielfältigung und Verbreitung zu gewerblichen Zwecken mit Hilfe fotomechanischer oder anderer Verfahren. Die Zeitschrift sowie alle in ihr enthaltenen einzelnen Beiträge und Abbildungen sind urheberrechtlich geschützt. Jede Verwertung, die nicht ausdrücklich vom Urheberrechtsgesetz zugelassen ist, bedarf der vorherigen schriftlichen Zustimmung des Verlags. Das gilt insbesondere für Vervielfältigungen, Bearbeitungen, Übersetzungen, Mikroverfilmungen und die Einspeicherung und Verarbeitung in elektronischen Systemen.

Autoren können unter bestimmten Voraussetzungen an der Ausschüttung der Bibliotheksund Fotokopietantiemen teilnehmen. Einzelheiten bei VG WORT, Abt. Wissenschaft, Goethestr. 49, 80336 München.

Angaben über Dosierungsanweisungen und Applikationsformen sind anhand anderer Literaturstellen oder der Packungsbeilage auf ihre Richtigkeit zu überprüfen. Der Verlag übernimmt keine Gewähr.

Indexed in Science Citation Index Expanded, Medline, EMBASE and Scopus

Mitglied der AG Kommunikationsforschung im Gesundheitswesen 
Abstracts

\section{Answers to clinical questions}

\section{1}

\section{Comparison of the bacterial microbiota in the skin of psoriasis patients before and after systemic TNF-alpha blockade}

\section{K. Loser', U. Dobrindt', T.A. Luger? \\ 'Universitätsklinikum Münster, Klinik für Hautkrankheiten}

Background. The skin represents the first barrier towards pathogens, but additionally acts as an ecosystem providing distinct niches for microbial communities. In this context, several studies suggested that microbes might influence the natural course of various skin diseases. Accordingly, Staphylococcus epidermidis was cultured from healthy skin and seems to protect humans from the invasion of pathogenic bacteria by secreting toxic anti-microbial peptides. Moreover, skin commensals have been shown to be involved in the induction, activation, and expansion of effector T cells demonstrating that the skin and the cutaneous microbiota co-exist in a well-established balance. However, these observations suggest that alterations in the composition of the cutaneous microbiota might promote the development and progression of skin diseases. In support of this, Staphylococcus epidermidis was significantly reduced in inflammatory skin from patients with atopic dermatitis whereas microorganisms directly associated with the progression of disease, like Propionibacterium acnes, were over-represented.

Recently, next-generation-sequencing approaches of $16 \mathrm{~S}$ rRNA genes have been used to characterize the cutaneous microbiota in healthy human skin compared to lesional skin from psoriasis patients. These studies revealed significant differences in the bacterial flora between lesional and non-lesional skin of the same patients and furthermore, resulted in the identification of microorganisms implicated in the pathogenesis of psoriasis. Bacteria of the phyla Staphylococcus, Firmicutes or Proteobacterium for instance, were over-represented in plaques whereas bacteria of the genera Actinobacterium or Propionibacterium were almost absent from inflammatory lesions.

Taken together, the development and progression of psoriasis seems to be associated with a substantial alteration in the composition of the cutaneous microbiota. Whereas the differences in the skin microbiota between healthy and lesional skin from psoriasis patients have been characterized, it is not clear if and how the cutaneous microflora changes after systemic treatment of patients.

Aims. Therefore, this project aims at investigating the cutaneous microbiota in lesional skin from the same psoriasis patients before and at different time points after TNF- $\alpha$ blockade with etanercept. As a control, the cutaneous microflora from psoriasis patients before and after treatment with etanercept plus methotrexate as well as before and after UVB-irradiation shall be characterized. The project is targeted to analyze whether changes in the skin microbiome are detectable before the amelioration of phenotypically evident disease parameters and furthermore, intends to dissect whether the resistance to therapy observed in some patients might be explained by the inability to eradicate „pathogenic“ bacteria from lesional skin.
1.2

Psoriatic arthritis genetics: risk factors in the IL-17 signalling pathway and in the transcriptional control of T cell differentiation

\section{B. Böhm ', F. Behrens', M. Köhm', H. Burkhardt'}

'Universitätsklinikum Frankfurt (M), Medizinische Klinik II/Rheumatologie

Psoriatic arthritis (PsA) is a common chronic inflammatory joint disorder that is closely associated with psoriatic skin disease. In a first genome-wide association study (GWAS) performed in close collaboration with our colleagues in the European Psoriatic Arthritis Consortium (PAGE), we were able to identify several genetic risk factors [1]. The finding of a PsA-associated genetic variant in the IL-17 signalling pathway seemed to be the most interesting with respect to its potential functional role in the pathogenesis of the disease. The mutant variant in the gene encoding the adapter protein Act- 1 causes an amino acid exchange at the amino terminus of the protein thereby disrupting its interaction with the downstream adapter protein TRAF6 in the signalling cascade from the IL-17 receptor to NF- $\mathrm{KB}$ activation [1]. Presently, we are investigating the molecular mechanisms that might explain how this loss-of-function mutation might contribute to pro-inflammatory pathways in PsA pathogenesis. We will present our strategy to investigate the functional impact of the mutation on cytokine signalling in genotyped cell lines and report on initial results. In addition, an update will be given on recent progress that has been made in the elucidation of the genetic predisposition to psoriatic arthritis by the PAGE-consortium. Thus, association with a variant in the $\mathrm{RUNX}_{3}$ gene, rs4649038, was replicated in independent patients and controls [combined $\mathrm{P}$ value of $1.40 \times 10(-8)$ by Cochran-MantelHaenszel test; odds ratio (OR) of 1.24]. Additional analyses based on linkage disequilibrium (LD) at $\mathrm{RUNX}_{3}$ revealed the most significant association in an LD block within the first intron of one isoform [2]. RUNX $_{3}$ has already been implicated in susceptibility to ankylosing spondylitis (AS). However, the AS-associated risk allele is independent of the newly identified PsA-associated variant. Since the transcription factor RUNX-3 is involved in CD8+ T lymphocyte differentiation the identified genetic variants might have an impact on adaptive immune responses in the T cell-mediated diseases of PsA and plaque psoriasis.

\section{References}

1. Hüffmeier $U$ et al (2010) Common variants at TRAF3IP2 are associated with susceptibility to psoriatic arthritis and psoriasis. Nat Genet 42(11):996-999

2. Apel M et al (2013) Variants in RUNX3 contribute to susceptibility to psoriatic arthritis, exhibiting further common ground with ankylosing spondylitis. Arthritis Rheum 65(5):1224-1231 
1.3

TNF- $a$ inhibitors induce restoration of peripheral regulatory $T$ cells and reduction of pro-inflammatory T cells in psoriatic skin lesions

\section{A. Jacobi', T. Carbone', A. Cavani', B.H. Greene ${ }^{3}$, R. Moll', M. Hertl', C. Möbs' 'Universitätsklinikum Hamburg-Eppendorf, Competenzzentrum Versor- gungsforschung in der Dermatologie - CVderm, Institut für Versorgungs- forschung in der Dermatologie und bei Pflegeberufen - IVDP, ${ }^{2}$ Labora- tory of Experimental Immunology, Rom, ${ }^{3}$ Philipps-Universität Marburg, Institut für Medizinische Biometrie und Epidemiologie, Fachbereich Medizin}

Background. Psoriasis is a chronic inflammatory disorder which is mainly orchestrated by proinflammatory T helper (Th) 1 and Th17 cells and commonly shows excellent therapeutic response to TNF- $\alpha$ antagonists.

Methods. The present study comprehensively investigated the dynamics of peripheral blood and lesional skin T cell subsets in a cohort of 26 patients with severe plaque-type psoriasis upon treatment with the TNF- $\alpha$ blockers, adalimumab $(n=13)$ and etanercept $(n=13)$ over 28 weeks.

Results. All patients showed a marked clinical improvement documented by a significant decrease of PASI and DLQI. Anti-TNF- $\alpha$ treatment led to the restoration of afore diminished peripheral $\mathrm{CD}_{4}+\mathrm{CD}_{25}+\mathrm{CD} 127$ low/- regulatory T cells (Treg) which was directly correlated to disease improvement. The numbers of Foxp $3+$ Treg cells in psoriatic skin lesions remained largely unaffected. Moreover, there was a significant decrease of the pro-inflammatory $\mathrm{T}$ cell infiltrate including Th17 cells in psoriatic skin after 8 weeks while peripheral effector T cell subsets remained unaffected.

Conclusions. Thus, anti-TNF- $\alpha$ therapy exerts at least two anti-inflammatory effects, i.e. the induction of peripheral Treg cells and the selective inhibition of the pro-inflammatory $\mathrm{T}$ cell infiltrate in skin lesions. These findings suggest that the clinical efficacy of TNF- $\alpha$ blockers in psoriasis is also linked to the induction of disease-modifying Treg cells.

\section{4}

\section{Role of TRPC channels in rheumatic diseases}

D. Umlauf', O. Lindeman', S. Harrach'3, S. Frank', B. Dankbar', H. Hidding', C. Cromme', M. Steiner', U. Kornak $^{5}$, B. Wieskoetter ${ }^{6}$, R. Stange', R.P. Marshall, F. Barvencik', A. Dietrich', A. Schwab', T. Pap ', J. Bertrand ${ }^{7}$

'Westfälische Wilhelms-Universität Münster, Institut für Experimentelle Muskuloskelettale Medizin, ${ }^{2}$ Westfälische Wilhelms-Universität Münster, Institut für Physiologie II, ${ }^{3}$ Westfälische Wilhelms-Universität Münster, Experimentelle Nephrologie, ${ }^{4} \mathrm{Helmholtz-Zentrum} \mathrm{Berlin} \mathrm{für}$ Materialien und Energie, ${ }^{5}$ Charité - Universitätsmedizin Berlin, Institut für medizinische Genetik und Humangenetik, ${ }^{6}$ Universitätsklinikum Münster, Klinik für Unfall-, Hand- und Wiederherstellungschirurgie, ${ }^{7}$ Universitätsklinikum Hamburg-Eppendorf, Institut für Osteologie und Biomechanik, ${ }^{8}$ Ludwigs-Maximilians-Universität München, WaltherStraub-Institut für Pharmakologie und Toxikologie

Background. Cell migration is crucial for many important physiological and pathophysiological processes ranging from embryogenesis to tumor metastasis and rheumatoid arthritis. It requires the coordination of mechanical forces generated in different regions of the migrating cell. It has been proposed that stretch-activated, $\mathrm{Ca} 2+$ permeable channels are involved in mechano-signaling during cell migration. It is generally agreed upon that members of the classical transient receptor potential channel family (TRPC) are involved in chemotaxis and cell migration. Here, we investigated the role of TRPC-1 in fibroblasts migration and osteoclasts formation.

Methods. For all in-vitro experiments, bone marrow macrophages (BMM) or fibroblasts were isolated from TRPC1-/- mice and corre- sponding wild type (WT) controls. For osteoclastogenesis BMMs were cultured in the presence of MCSF and RANKL. Using quantitative real-time PCR mRNA levels of TRPC1, Dc-Stamp and NFATC1 were analysed. Fibroblasts were stimulated with TNF alpha. Fibroblast vitality was analysed using a MTT assay. Time-lapse video microscopy was used to study osteoclast and fibroblast migration and osteoclast fusion. The intracellular $\mathrm{Ca} 2+$ concentration was measured ratiometrically with the fluorescent Ca2+ dye Fura-2, with and without mechanical stimulation. The skeletal phenotype of 16 -week old mice was investigated by $\mu \mathrm{CT}$-analyses of trabecular bone in the lumbar spine. Ovariectomy was performed on 12-week old sex- and aged-matched littermates as a model for human postmenopausal bone loss.

Results. PCR analyses revealed that TRPC1 is hardly expressed in monocytes and pre-osteoclasts, but gets upregulated during osteoclast-differentiation. As seen in $\mu \mathrm{CT}$ analysis, TRPC1-/- mice showed no differences in bone phenotype compared to WT mice under physiological conditions. However, in the ovariectomy model of estrogendeficiency mediated bone loss, TRPC1-/- mice exhibited a reduced loss of trabecular bone volume (-28.9\% in WT compared to $-13.1 \%$ in TRPC1-/-) and bone tissue density ( $-3.2 \%$ in WT compared to $+0.9 \%$ in TRPC1-/-) in LW5. Analysing the underlying signaling pathways, we found no differences in Ca2+-oscillations and store-operated calcium entries and no differences in NFATC1 expression. In time-lapse microscopy, however, we observed a reduced capacity of TRPC1-/osteoclast precursors to migrate and to fuse, due to a reduced velocity, translocation and a reduced increase of cell area over time. The same migratory defect was observed for fibroblasts when mechanical stimulated, as well as fibroblasts stimulated with TNF alpha. The MTT assay revealed a decreased cell viability, which was even more pronounced under stimulation with TNF alpha.

Conclusions. These results provide the evidence that TRPC1 is essential for migration of different cell types. Furthermore, it seems to be necessary for the fusion of osteoclasts. We have shown that the loss of TRPC 1 while not affecting physiological bone turnover has a clear effect on accelerated bone loss as seen in estrogen deficiency. Additionally, TRPC 1 might also play a role under inflammatory conditions. Thus, our data implicate that TRPC1 may represent a potential target for treating rapid osteoporotic bone loss like during rheumatoid arthritis.

\section{From nano to macro}

\section{1}

Molecular imaging of bone pathology using high-resolution SPECT and enhanced MRI in patients with early rheumatoid arthritis and methotrexate therapy

P. Sewerin', C. Buchbender', F. Miese2 , K. Matthes-György', H.-J. Wittsack², M. Schneider', A. Scherer', B. Ostendorf'

'Universitätsklinikum Düsseldorf, Poliklinik und Funktionsbereich Rheumatologie, ${ }^{2}$ Universitätsklinikum Düsseldorf, Institut für Diagnostische und Interventionelle Radiologie, ${ }^{3}$ Universitätsklinikum Düsseldorf, Institut für Nuklearmedizin

Background. To evaluate the utility of high resolution multi pinhole single photon emission computed tomography (MPH-SPECT) and magnetic resonance imaging (MRI) for detecting of bony alterations in early rheumatoid arthritis (ERA) and to differ them from early osteoarthritis (EOA).

Methods. The clinical dominant hand of 52 consecutive patients ( 35 ERA, 12 EOA, 5 healthy controls) was examined by MPH-SPECT with technetium-99m-labeled disphosphonat (Tc99-DPD). Additionally, in 35 of them (23 ERA, 7 EOA and 5 healthy controls) we performed a MRI of the same hand. In the ERA group we initiated a methotrexate 
therapy and repeated the procedure after 6 month. Number of affected joints, localisation, pattern of tracer distribution and joint involvement were scored. Quantitative analysis was achieved by measurement of the region of interest (ROI) in all patients. The MPH-SPECT and MR images were fused in all patients who received both methods. Results. With MPH-SPECT central tracer distribution was typical for ERA (16/23 patients, $1 / 7$ in EOA). In contrast, an eccentric pattern was found predominantly in EOA (6/7 patients, $4 / 23$ in ERA). The frequency of increased TC99m-DPD uptake, synovitis and bone marrow oedema decreased under MTX therapy, but the numbers of bone erosions increased. Joints with progressive and new erosions on follow-up had a higher baseline TC99m-DPD uptake (2.64 \pm 1.23 vs. $1.43 \pm 0.91, \mathrm{p}=0.02$ ). Conclusions. MPH-SPECT is sensitive to early changes in ERA and EOA and permits them to be distinguished by their pattern of uptake. Joints with erosive progression are characterized by an early increased Tc99m-DPD uptake even in absence of MRI bone pathologies (e.g. osteitis). Tc99m-DPS MPH-SPECT because of higher sensitivity to bone metabolism changes might be of additional value to morphological MRI identification and therapy monitoring of ERA patients with high risk for erosive progression.

\section{2}

\section{Synovial inflammation analysed by soluble adhesion molecules and 3 Tesla magnetic resonance imaging in etanercept-treated patients with rheumatoid arthritis}

\section{Oleszowsky', W. Willinek' ${ }^{2}$, S. Ebbinghaus' ${ }^{3}$, M.F. Seidel' \\ 'Universitätsklinikum Bonn, Medizinische Klinik und Poliklinik III, Klinik für Hämatologie, Onkologie und Rheumatologie, ${ }^{2}$ Universitätsklinikum Bonn, Radiologische Klinik, ${ }^{3}$ Ruhr-Universität Bochum, Fakultät für Chemie und Biochemie}

Background. Conventional disease-modifying anti-rheumatic drug (cDMARD) treatment is insufficient in some patients with rheumatoid arthritis (RA) thus requiring antagonists for TNF- $\alpha$. Treatment with these agents demonstrates excellent remission rates documented with conventional radiographs and some magnetic resonance imaging (MRI) studies. The 3 Tesla technique allows higher spatial resolution as compared to 1.5 Tesla analysis. Especially early and thus prognostically relevant subchondral bone lesions might be detected more precisely. In addition, serum levels of soluble isoforms of vascular cell adhesion molecule-1 (sVCAM-1), intercellular adhesion molecule-1 (sICAM-1) and endothelial-leukocyte adhesion molecule-1 (sELAM-1) might be serological indicators of synovial activation and may correlate to inflammatory infiltrates.

Methods. Ongoing epidemiologic clinical pilot MRI study with 10 ACR/EULAR-positive, RA patients with inadequate response to two cDMARDs and thus an indication for etanercept (ETA) using the rheumatoid arthritis magnetic resonance imaging system (RAMRIS). These patients are compared to 10 patients adequately responding to cDMARDs. 3 Tesla MRI (PDSPAIR; T1 with and without contrast agent) using a multi-channel hand coil are performed at baseline, after four months, and after 12 months. MRI analyses include RAMRIS scoring with examination for synovitis, effusion, subchondral erosion, and also bone marrow edema. Data are compared to and correlated with, sVCAM-1, sICAM-1, sELAM-1 and clinical parameters such as DAS 28 (CRP).

Results. Up to date, 10 ETA-treated patients were included. Data at baseline, after four months and after 12 months are available for 9 patients. The mean $( \pm S D)$ total RAMRIS changed from $30.4( \pm 16.2)$ to $28.9( \pm 14.0)$ to $24.0( \pm 13.0)$ after one year. DAS 28 decreased from $3.8( \pm 1,2)$ to $3.1( \pm 1.0)$ and $2.4( \pm 0.9)$. Baseline data from 7 cDMARD patients $( \pm \mathrm{SD}$; p-values compared to etanercept treatment) were as follows: RAMRIS 10,8 ( $\pm 9.4 ; \mathrm{XX})$ and DAS 281.7 ( \pm 0.6 ; XX). None of the soluble adhesion molecule concentrations significantly changed over time. However, sVCAM was significantly higher in ETA patients at baseline $(662.1 \mathrm{ng} / \mathrm{ml} \pm 132.7)$ as compared to cDMARD patients (225.0 $\mathrm{ng} / \mathrm{ml} \pm 89.7)$ and healthy controls $(356.1 \mathrm{ng} / \mathrm{ml} \pm 225.1)$.

Conclusions. The results indicate a reduction in synovial activity after 12 months of treatment with ETA with respect to RAMRIS and DAS 28. Although soluble adhesion molecules did not change over time sVCAM indicated a differential overexpression in ETA patients in this small cohort. More patients and data after 12 months are still required for final analyses.

\section{3}

Magnetic resonance assessment and therapy monitoring of cardiovascular involvement in rheumatoid arthritis

\section{B. Langhans', H. Schulze-Koops ${ }^{2}$, M. Witt' ${ }^{2}$, T. Saam', M. Gruenke ${ }^{2}$}

${ }^{1}$ Klinikum der Universität München, Institut für Klinische Radiologie, ${ }^{2}$ Klinikum der Universität München, Medizinische Klinik und Poliklinik IV, Rheumaeinheit

Background. Rheumatic diseases have been associated with accelerated atherosclerosis leading to an up to 3 -fold increased risk for $\mathrm{CV}$ events such as myocardial infarction or stroke $[1,2]$. The pathogenesis of atherosclerosis and RA involves similar pathomechanisms such as inflammatory cells and pro-inflammatory cytokines, e.g. tumor necrosis factor (TNF) [3]. Recent studies have shown that TNF antagonists may improve endothelial function in RA patients and therefore may minimize cardiovascular risk in RA $[3,4]$. However, studies to confirm the cardiovascular effect of biologic agents on carotid wall thickness (CWT), plaque composition and inflammation or myocardial inflammation/fibrosis in RA do not exist.

Methods. Single-blinded, cross sectional study to evaluate differences in carotid plaque burden, plaque composition and plaque inflammation as assessed by carotid MRI as well as the prevalence of myocardial inflammation/fibrosis and left ventricular dysfunction by cardiac MRI between two distinct patient groups: (i) 25 RA patients with newly initiated Etanercept treatment; (ii) 20 age- and gender matched patients with similar cardiovascular risk profile and without any evidence of systemic inflammatory disease. Longitudinal study design to assess the impact of 12-months of Etanercept therapy on the before mentioned MRI characteristics of cardiovascular involvement. Subjects in this trial should be at least 55 years of age to form a cohort at risk for cardiovascular disease. Imaging will be performed at $3 \mathrm{~T}$ using a contrast-enhanced, multi-sequence protocol including dynamic contrast enhanced sequences of carotid plaques, cardiac late gadolinium enhancement (LGE) and T1-mapping (shMOLLI).

Results. Primary imaging endpoints: differences in plaque burden, plaque inflammation, and presence of LGE in RA patients and control. Secondary imaging endpoints: MRI changes in mean and maximum \%lipid/rich necrotic core, \%fibrous tissue and \%calcification of carotid plaques and in diffuse myocardial fibrosis (ECV fractions, $\mathrm{T} 1$ mapping), global LV function and LV volumes after 1 year of Etanercept treatment. Secondary clinical endpoints: changes of RA disease activity (DAS28), functional disability (HAQ disability index) and Framingham Risk Score.

Conclusions. We want to assess the potential beneficial effect of TNF antagonist treatment on (i) early cardiac involvement by T1-mapping, functional cardiac analysis and LGE imaging and (ii) on plaque burden and plaque inflammation measurements by multi-sequence carotid MRI after 12 months of Etanercept treatment.

\section{References}

1. Solomon DH, Kremer J, Curtis JR et al (2010) Explaining the cardiovascular risk associated with rheumatoid arthritis: traditional risk factors versus markers of rheumatoid arthritis severity. Ann Rheum Dis 69:1920-1925

2. Crowson CS, Matteson EL, Roger VL, Therneau TM, Gabriel SE (2012) Usefulness of risk scores to estimate the risk of cardiovascular disease in patients with rheumatoid arthritis. Am J Cardiol 110:420-424 
3. Soltesz P, Kerekes G, Der H et al (2011) Comparative assessment of vascular function in autoimmune rheumatic diseases: considerations of prevention and treatment. Autoimmun Rev 10:416-425

4. Peters MJ, Symmons DP, McCarey D et al (2010) EULAR evidence-based recommendations for cardiovascular risk management in patients with rheumatoid arthritis and other forms of inflammatory arthritis. Ann Rheum Dis 69:325-331

\section{4}

Comparing the OMERACT Psoriatic Arthritis Magnetic Resonance Imaging Score (PsAMRIS ) with PSA-like joint alterations detected by Mikro-CT in patients with psoriasis without clinical symptoms of psoriatic arthritis

\section{J. Rech ${ }^{7}$ \\ 'Universitätsklinikum Erlangen, Medizinische Klinik III, Rheumatologie \& Immunologie}

Background. Psoriatic arthritis (PSA) is a chronic polyarthritis spectrum disorder strongly associated with cutaneous manifestations of psoriasis. There are several classification criteria for the diagnosis of PSA, the CASPAR classification criteria being established most recently. Its parameters cover aspects of psoriasis and arthritis as well as laboratory and radiological variables. Up to $30 \%$ of patients with psoriasis develop PSA. Imaging, especially magnetic resonance imaging (MRI) and ultrasonography, has allowed us to explain the relationships between enthesitis, synovitis (or the synovio-entheseal complex) and osteitis or bone oedema in PsA. The hrpqCT $(\mu \mathrm{CT})$ technique enables us to detect periarticular bone alterations typical for RA (4) and PSA in a highly sensitive and specific manner. We also were able to detect even in asymptomatic patients (17/30 patients) with psoriasis periarticular bone alterations typical for PsA. These early alterations involve the whole circumference of the bone, leading to new bone formation. In the course of the disease, cortical thinning as a sign of subclinical osteoporosis occurs, presumably due to periosteal inflammation.

Methods. Routine treatment (including the following reliable scores: PASI, DAS28, HAQ) of subjects will be complemented by a CT-scan with XtremeCT and a Hand MRI.

Results. We have been able to enrol more than 30 patients so far. The analysis is still ongoing.

Conclusions. In asymptomatic patients with psoriasis and PSA-like joint alterations measured by hrpq-CT, inflammation is detectable by MRI.

\section{5}

Characterization of bone changes in ACPA-positive individuals without signs of arthritis compared to ACPA-negative, healthy subjects with HR-pQCT measurements of MCP joints

\section{A. Kleyer', S. Finzel', J. Rech', G. Schett' \\ 'Universitätsklinikum Erlangen, Medizinische Klinik III, Rheumatologie \& Immunologie}

Objective. Anti-citrullinated protein antibodies (ACPA) are a major risk factor for bone loss in rheumatoid arthritis (RA) and can be detected years before clinical onset of RA. Since recent research work shows that ACPA directly induce bone loss by stimulating osteoclast differentiation, we hypothesized that ACPA positive healthy individuals may already show skeletal changes.

Methods. We performed a comparative micro-computed tomography analysis (XtremeCT, Scanco, $82 \mu \mathrm{m}$ isotropic Voxelsize) of the bone microstructure in the metacarpophalangeal joints two and three of ACPA positive and -negative healthy individuals without clinical signs of arthritis.
Results. ACPA positive $(\mathrm{N}=15)$ and -negative $(\mathrm{N}=15)$ healthy individuals were not different in age $(48.2 \pm 4.1$ vs. $51.4 \pm 3.8$ years, $\mathrm{p}=0.57)$ and gender (each 8 females and 2 males). Bone mineral density was significantly reduced in ACPA-positive individuals (mean \pm SEM: $\left.280 \pm 11 \mathrm{mg} / \mathrm{cm}_{3}\right)$ as compared to controls $(327 \pm 6)$. Bone loss was based on cortical bone changes with significant $(\mathrm{p}=0.044)$ reduction in cortical thickness in the ACPA-positive group (mean \pm SEM: $0.22 \pm 0.03 \mathrm{~mm})$ as compared to controls $(0.32 \pm 0.03 \mathrm{~mm})$. Areas of cortical porosity were significantly $(\mathrm{p}=0.0005)$ more widespread in ACPA-positive (mean \pm SEM: $7.4 \pm 1.4 \%$ ) than in ACPA-negative individuals (1.0 $\pm 0.3 \%)$.

Conclusion. Structural bone damage starts before the clinical onset of arthritis in subjects with ACPA. These findings may revise the concept that bone damage is an exclusive consequence of synovitis in patients with rheumatoid arthritis

\section{Clinical studies}

\section{1}

Indicators of depression are stronger predictors of work disability in early arthritis than disease activity or response to therapy

\section{G. Westhoff', J. Callhoff', Matthias Schneider' ${ }^{2}$, A. Zink ${ }^{7}$}

'Deutsches Rheuma-Forschungszentrum Berlin, ${ }^{2}$ Universitätsklinikum Düsseldorf, Poliklinik für Rheumatologie

Background. The decision to stop working in patients with early inflammatory arthritis (IA) is influenced by a wide range of factors besides arthritis disease activity. We assessed the association between patients' characteristics at arthritis onset and the consideration or decision to request disability pension.

Methods. 501 gainfully employed patients $\leq 63$ years of age enrolled in an early IA cohort ( $<6$ months) were analyzed with respect to their consideration to go for early retirement within the first 12 months of rheumatologic care. Independent variables in multivariate logistic regression were sex, education, BMI, RF and/or ACPA serology, acute phase reactants (CRP and ESR normal/abnormal), tender and swollen joint counts (T/SJC28), and 12 physician reported common chronic conditions. Patient-reported parameters included pain, morning stiffness, fatigue, functional capacity $(\mathrm{FFbH})$ and the first item of the $\mathrm{Pa}$ tient Health Questionnaire Depression scale (PHQ9): "Having little pleasure or interest in doing things during the last two weeks" (not at all, on several days, more than half of the days). The analysis was adjusted for age.

Results. Patients ( $67 \%$ female) were $47 \pm 10$ years old and had symptom duration of $13 \pm 7$ weeks. $67 \%$ were RF and/or ACPA positive and $65 \%$ fulfilled the new ACR-EULAR RA criteria at baseline. At 12 months, 36 of the patients were considering applying for early retirement, 14 had applied and 12 had gone into early retirement. These 62 patients were about 6 years older and had significantly higher disease activity and severity, within the first year. However, none of the arthritis activity measures or any of the considered cardiovascular, metabolic or pulmonary diseases was associated with early retirement in multivariate analysis. Instead, the highest association was found with "having little pleasure or interest in doing things most of the days" (Tab. 1). Overall, $10.6 \%$ of the patients reported that problem; $30 \%$ of them were considering early retirement or had gone into.

Conclusions. Whether or not patients with early arthritis are considering applying for disability pension depends more on mental conditions than on disease activity. Since one single depression statement was able to identify patients with an increased risk of early retirement, well-directed attention on the patient's well-being in the early stages of the disease may help the patients to remain in the labour force. 
Tab. 1 | 3.1 Adjusted odds ratios (OR) of conditions that increase the probability to go for early retirement

\begin{tabular}{|lllllll}
\hline & $\mathrm{n}$ & Reference & $\mathrm{n}$ & $\mathrm{OR}$ & $95 \% \mathrm{Cl}$ & $\mathrm{P}$ \\
\hline Age, years & 501 & Per year & & 1.10 & $1.06-1.15$ & $<0.001$ \\
\hline Spine disease & 25 & No & 476 & 3.04 & $1.05-8.83$ & 0.041 \\
\hline Functional capacity $50-70 \%$ & 86 & $71-100 \%$ & 369 & 2.61 & $1.15-5.95$ & 0.022 \\
\hline Functional capacity $<50 \%$ & 46 & $71-100 \%$ & 369 & 3.22 & $1.63-6.37$ & 0.001 \\
\hline $\begin{array}{l}\text { Having little pleasure or interest } \\
\text { on several days (PHQ9-1) }\end{array}$ & 243 & Not at all & 205 & 3.40 & $1.67-7.75$ & 0.002 \\
\hline $\begin{array}{l}\text { Having little pleasure or interest } \\
\text { most of the days (PHQ9-1) }\end{array}$ & 53 & Not at all & 205 & 8.67 & $3.35-22.43$ & $<0.001$ \\
\hline
\end{tabular}

\section{2}

\section{Functional capacity of JIA patients at the starting point of an anti-TNF- $a$ therapy - preliminary results}

\section{Hartmann', F. Kreuzpointner, ${ }^{1,2}$, A. Schwirtz' ${ }^{2}$ J.P. Haas' \\ 'Deutsches Zentrum für Kinder- und Jugendrheumatologie, Garmisch- Partenkirchen, ${ }^{2}$ Fachgebiet für Biomechanik im Sport, Fakultät für Sport- und Gesundheitswissenschaft, Technische Universität München}

Background. Currently $33 \%$ of patients with polyarticular JIA are treated with biologics (Minden et al. 2013). Despite the substantial improvement according to disease activity (e.g. Hashkes et al. 2010) achieved by anti-TNF- $a$ treatment, patients still suffer from functional impairments. There has been no objective measuring parameter for the assessment of functional effects on joint limitations established so far. The aim of this work is to verify the functional capacity of JIA patients with initial adjustment to an anti-TNF- $\alpha$ therapy combined with functional treatment in comparison to healthy controls and JIA controls with an inactive disease level.

Methods. In a prospective study on polyarticular JIA patients treated with anti-TNF- $\alpha$ therapies plus functional therapies longitudinal effects on joint function have been analysed. The measurements include 3d gait analysis (eight Vicon F4o cameras, OMG, London), balance control ( $S_{3}$-check, TST, Großhoeflein), pedobarography [emed plate (4sensors/cm2, Novel, Munich)], daily activity assessment (Step Watch, Orthocare Innovations, OK USA), ACR pedi and joint mobility testing. The cross-sectional data of the first 17 patients in the intervention group ( $15.0 \pm 3.1 \mathrm{yrs}, 162.7 \pm 14.6 \mathrm{~cm}, 60.0 \pm 17.2 \mathrm{~kg}$, pain-level: 4.8 $\pm 1.7 / 10$ VAS, active joints: $6.2 \pm 5.9, \mathrm{CHAQ}: 0.4 \pm 0.4)$ are presented and compared with JIA-patients control group $(n=21,14.0 \pm 2.3 \mathrm{yrs}$, $162.3 \pm 9.5 \mathrm{~cm}, 54.4 \pm 14.1 \mathrm{~kg}$, pain-level: no information, active joints: o, CHAQ: $0.3 \pm 0.5)$ as well as healthy age matched controls $(n=9$, $14.0 \pm 2.8 \mathrm{yrs}, 162.0 \pm 5.4 \mathrm{~cm}, 51.8 \pm 6.4 \mathrm{~kg}$ ). For the statistic examination on differences a student's t-test was used. The results are secured on a probability level of $95 \%$.

Results. These preliminary results demonstrate that the ability to walk is limited in the intervention group. Patients have a reduced push off power generation within the ankle joint (patients: $3.4 \pm 1.4 \mathrm{~W} / \mathrm{kg}$; healthy controls: $4.5 \pm 0.9 \mathrm{~W} / \mathrm{kg}(\mathrm{p}<0.05)$. Furthermore a limited sensory motor control and stability in comparison to patients with an inactive disease status has been observed while performing balance tests [patients: sensory-index: $2.9 \pm 1.0$, stability-index: $3.7 \pm 1.1$, JIA controls: sensory-index: $2.1 \pm 0.8$, stability-index: $3.0 \pm 1.0$ (both $\mathrm{p}<0.05)$ ]. Note: lower indices values are better results.

Conclusions. This is one of the first studies which show functional joint-specific deficits during every day activities in patients who receive an initial anti-TNFa therapy. The limited stability and motor control might be due to limited joint integrity in the ankle joint. This is supported by the impaired push off function while walking. The next study step will show possible effects of the anti-TNFa therapy.

\section{References}

1. Hashkes PJ et al (2010). Nat Rev Rheumatol 6(10):561-571

2. Minden $\mathrm{K}$ et al (2013). Z Rheumatol 72(4):339-46
3.3

Remission induction by etanercept in enthesitis-related arthritis JIA patients (juvenile undifferentiated spondyloarthropathy) REMINDER-Study

\section{G. Horneff}

\section{${ }^{1}$ Asklepios-Klinik Sankt Augustin GmbH}

Background. Enthesitis-related arthritis is a juvenile idiopathic arthritis category, clinically related to the syndrome of undifferentiated spondyloarthropathy in adults. This study is intended to generate first evidence that treatment with etanercept is safe and effective in patients diagnosed with ERA-JIA who are able to acquire stable remission (inactive disease). Furthermore the stability of remission off medication in patients treated with etanercept will be demonstrated.

Methods. This is a multi-center, open-labeled uncontrolled study of 24 weeks, followed by randomized, double-blind, placebo-controlled, withdrawal, parallel group treatment phase of further 24 weeks. In phase 1 , a total of 40 patients with ERA-JIA are treated with etanercept (0.8 mg/kg up to a max of $50 \mathrm{mg} s c$ per week) for 24 weeks. Patients who demonstrated at least a PedACR 30 response in phase 2 will be randomised to two groups. Group 1 will continue treatment with etanercept for a maximum of further 24 weeks. Group 2 will receive placebo and will be followed up to observe the duration of a remission without therapy. The study phase 2 is terminated in case of a disease flare or after 24 weeks, whichever occurs earlier. Patients who flare in will enter phase 3 , an open label extension phase. Patients who do not flare until week 48 will terminate the study.

Results. The study is ongoing. 40 patients $(67 \%$ male) have been recruited so far. 29 patients have reached week 24,23 patients (77\%) exhibited no tender joint, 28 patients (93\%) no swollen joint, 23 patients (77\%) no active joint, 18 patients $(60 \%)$ showed a physician global indicating no disease activity, 28 patients $(100 \%)$ had a normal ESR $(<20 \mathrm{~mm} / \mathrm{h}), 26$ patients $(87 \%)$ had a normal CRP $(<5 \mathrm{mg} / \mathrm{l}), 25$ patients $(83 \%)$ had no tender enthesitis points. "Inactive disease" could be documented in 18 patients (6o\%). At week $2497 \% / 97 \% / 87 \% / 67 \% / 63 \%$ of patients reached the PedACR $30 / 50 / 70 / 90 / 100$ criteria. So far, 1 patient did not reach $\mathrm{ACR}_{3} \mathrm{O}$ at week 24 and was not randomized. 29 patients were already randomized to receive placebo or etanercept, 10 flares occurred, 4 at week 28 and 4 at week 32, 18 patients reached week 48 without a flare. 2 patients were withdrawn from the study, one for allergic skin reaction, one for protocol violation. So far 91 adverse events have been observed, 12 cases with gastroenteritis, 9 with headache, 15 with upper airway infection, all other occurred less than 23 times. One serious adverse event, a posttraumatic renal hemorrhage, judges as not related to study drug was documented.

Conclusion. In this ongoing study etanercept proved to be an effective therapeutic approach for patients with enthesitis-related arthritis (ERA-JIA) with a high rate of responders and a high rate of patients reaching "inactive disease" after 24 weeks of treatment. Since the study is still recruiting and blinded all results are preliminary. There was no new safety information. 
3.4

\section{Psycho-pathologic comorbidities in psoriasis}

\section{J. Wohlrab}

'Universitätsklinikum Halle (Saale) Universitätsklinik und Poliklinik für Dermatologie und Venerologie

Background. Psychological stress, i.e. anticipatory anxiety concerning the prognosis of severe psoriasis, and mental disorders requiring special treatment, i.e. depression, are quite common concomitant symptoms in patients with chronic skin diseases. These should not only be seen as psychological reaction to a stressful situation but as a variety of conditions - the actual disease, the treatment, individual coping capacities and a vulnerability regarding mental illness - embedded in a complex structure. In addition, there are neurobiological, psychological and social interactions in patients with psoriasis and potential psychological and mental comorbidities that have not been fully understood yet. With this in mind the need to offer and provide for psychosocial support for psoriatic patients seems obvious.

Methods. The main objective of this project is the detection of the most common mental disorders in psoriatic patients, as a first step to extend the knowledge about the variety of the individual disorders. Supplemented with the dermatological history and a physical examination, it should be possible to reveal correlations with disease severity and duration. Therefore, a multicentre consortium of psoriasis study centres in Germany will use the Patient Health Questionnaire (PHQ) supplemented by questions about medical history and dermatological disease data for psoriasis (PASI, DQLI) to conduct a survey with 200 patients with moderate or severe psoriasis.

Results. The project starts in June 2013 and will be finished in summer 2014.

\section{Prognosis and outcome}

\section{1 \\ Determination of TNFa blocker serum levels and anti drug antibodies during long term treatment of rheumatoid arthritis patients and their association with clinical outcome and selected biomarkers}

\section{S. Drynda, ${ }^{1,2}$ J. Kekow ${ }^{1,2}$ \\ 'Otto-von-Guericke-Universität Magdeburg, Klinik für Rheumatologie, ${ }^{2}$ Fachkrankenhaus Vogelsang-Gommern, Fachkrankenhaus für Rheuma- tologie, Orthopädie und Schmerztherapie,}

Specific targeting of tumor necrosis factor alpha (TNFa), the key cytokines in the pathogenesis of rheumatoid arthritis (RA), has substantially improved the treatment options in RA. However, besides primary therapy failure occuring in about $30 \%$ of patients, secondary therapy failure patients require treatment changes. As one possible mechanism responsible for secondary drug failure the generation of anti-drug antibodies (ADA) is considered. ADAs are supposed to change the pharmacokinetics or even neutralize the drug resulting in sub-therapeutic drug levels. Evidence that measurements of drug levels and ADA are clinically relevant for individual patients is consistently growing, thus therapeutic drug monitoring has become a new aspect in the treatment of patients with rheumatic diseases. Whether ADAs develop in the course of a biological therapy depends from different factors. From the site of the drug structural properties as well as dosage of drugs and co-medication with immunosuppressive therapy are considered as factors that influence ADA formation. Long term studies on ADA formation under various conditions, however, are missing. Additionally, there exist patient related factors that are discussed as predisposing factors that influence the ADA forma- tion. A specific genetic background as well as high disease activity are considered possible factors for ADA formation.

Three major questions will be addressed in this study. First we want to analyze the occurrence of ADAs in long-term treatment of RA patients with TNF blockers (Etanercept and Adalimumab) and its impact on drug levels. Secondly we want to identify patient specific markers that are associated with the formation of ADAs. Finally we plan to analyse the effect of a B-cell directed therapy on antibodies against TNF blockers. The study is planned as a retrospective non interventional post-hoc biobank analysis including 175 RA patients (100 patients treated with Etanercept, 50 patients treated with Adalimumab and 25 patients with an intermediate period with Rituximab). Serum samples from clinically, serologically and genetically characterized RA patients treated with TNF blockers were collected over up to 10 years in a biobank established at the Rheumatology Research Lab in Magdeburg.

The identification of patient specific markers that are associated with a high risk for developing ADA could affect existing treatment pathways and will be a central challenge addressed by our study.

\section{2}

Validity of additional use of optical immunofluorescence imaging technique (Xiralite ${ }^{\oplus}$ ) in detection of active psoriatic arthritis and measurement of disease activity in patients with psoriasis and psoriatic arthritis

M. Köhm ${ }^{1,2}$, T. Roßmanith ${ }^{2}$, H. Burkhardt',2, F. Behrens ${ }^{1,2}$

'Johann Wolfgang Goethe-Universität Frankfurt, Medizinische Klinik II/ Rheumatologie, ${ }^{2}$ Fraunhofer IME, Translationale Medizin und Pharmakologie TMP Frankfurt/Main

Psoriatic arthritis (PsA) is a common chronic inflammatory joint disorder that is closely associated with psoriatic skin disease. Mostly, musculoskeletal involvement occurs after skin manifestations [1]. In early manifestations of PsA, changes in synovial vascularisation combined with increased expression of pro-angiotic factors appear [2]. Therefore, imaging principles for detection of changes in vascularisation can be used for early detection of joint disease and monitoring of disease activity. Xiralite ${ }^{\star}$ is a new fluorescence optical imaging device licensed for the detection of changes in microvascularisation of the hands. The method is tailored to the contrast agent ICG (indocyanine green; e.g. ICG-Pulsion ${ }^{\star}$ ), which is approved in Europe as an agent for imaging diagnostics of microcirculation. After intravenous contrast administration, altered microcirculation of joints, tendons, bones and ligaments will be displayed due to an increased signal of the contrast agent [3]. Validity and sensitivity of Xiralite ${ }^{\circ}$ will be examined in two different scenarios: Validity and sensitivity of Xiralite in early detection of musculoskeletal involvement will be observed in patients with psoriasis having risk for development of musculoskeletal disease (XCITING study). Therefore, Xiralite ${ }^{\circledast}$ imaging will be compared to clinical examination and ultrasound.

In a second project, changes in disease activity will be measured by Xiralite and correlated to clinical examination/ultrasound in a homogeneous patient-group with a standardized treatment regimen with Etanercept (XPLORE study). Both projects will be conducted at 12 centres in Germany. The enrolment period has recently started.

\section{References}

1. Ruderman EM, Tambar S (2004). Psoriatic arthritis: prevalence, diagnosis, and review of therapy for the dermatologist. Dermatol Clin 22(4):477-486

2. Fearon U, Reece R, Smith J, Emery P, Veale DJ (1999) Synovial cytokine and growth factor regulation of MMPs/TIMPs: implications for erosions and angiogenesis in early rheumatoid and psoriatic arthritis patients. Ann N Y Acad Sci 878:619-621

3. Werner SG et al (2011) Inflammation assessment in patients with arthritis using a novel in vivo fluorescence optical imaging technology. Ann Rheum Dis, Oct 12 


\section{3}

Sparing methotrexate in seropositive patients with rheumatoid arthritis results in a less stringent control of the adaptive immune system

\section{U. Saunders', T. Fassbinder', H. Becker', E. Jung', E. Mickholz', P. Willeke', B. Schlüter', A.M. Jacobi' \\ 'Universitätsklinikum Münster, Medizinische Klink D (Allgemeine Innere Medizin sowie Nieren- und Hochdruckkrankheiten und Rheumatologie), ${ }^{2}$ Universitätsklinikum Münster, Centrum für Laboratoriumsmedizin}

Objective. Clinical trials revealed that tumor necrosis factor alpha (TNF- $\alpha$ ) blockade is more effective if administered with concomitant methotrexate (MTX). Based on an observation made when studying $B$ cell subsets in patients with seropositive (sp) RA this study aimed to investigate the main mechanisms of action MTX exerts on the adaptive immune system.

Methods. Peripheral blood samples of $78 \mathrm{spRA}$ patients divided into four treatment groups (MTX: $n=23$, TNF- $\alpha$-inhibitor: $n=23$, MTX/ TNF- $\alpha$-inhibitor: $\mathrm{n}=17$ and patients without MTX/TNF- $\alpha$-inhibitor: $\mathrm{n}=15$ ) were obtained and lymphocyte cell subsets were analyzed by multiparameter flow cytometry. To investigate the effect of MTX on $\mathrm{B}$ cell proliferation and differentiation in vitro cell culture assays were performed.

Results. SpRA patients treated with MTX as monotherapy or in combination with TNF-blockade exhibited significantly lower frequencies and numbers of $\mathrm{CD}_{2} 7$ highCD 38 high plasmablasts and a lower serum concentration of free light chains (FLC) compared to patients on antiTNF- $\alpha$ monotherapy. MTX had no effect on in vitro proliferation, differentiation, and survival of purified B cells, but patients taking MTX showed significant lower numbers of $\mathrm{CD}_{45} \mathrm{RO}+$ memory and CD44+CD62Llow effector T helper cells compared to patients not on MTX. Differentiated Thelper cell subsets correlated significantly with plasmablast counts as did FLC and mutated citrullinated vimentin (MCV) antibody levels. In contrast to plasmablasts counts FLC concentrations were correlated with DAS28.

Conclusion. Adding to the beneficial effect of TNF- $\alpha$-inhibitors, MTX seems to correct the aberrant B cell activation in spRA indirectly by influencing the activation and differentiation of $\mathrm{T}$ helper cells. These findings argue for concomitant use of MTX with TNF- $\alpha$-inhibitors to increase therapeutic efficacy.

\section{4 \\ Diagnostische und prognostische microRNAs in rheumatoider Arthritis}

\section{S. Sesselmann', H.M. Jäck², J. Wittmann²}

'Friedrich-Alexander Universität Erlangen-Nürnberg, Orthopädische Klinik und Poliklinik, ${ }^{2}$ Abteilung für Molekulare Immunologie an der Medizinischen Klinik III, Nikolaus-Fiebiger-Zentrum, Universitätsklinikum Erlangen

Background. Rheumatoid arthritis (RA) is the most common inflammatory/degenerative rheumatic disease of the joints with a worldwide prevalence of $0.5-1 \%$, women being affected 3 times more often than men. Generally, people of all ages can suffer from RA, with a peak incidence between 35 and 45 years of age. Although the exact cause(s) of RA is unknown, autoimmunity plays a pivotal role in its chronicity and progression. A primary role in the pathogenesis of RA is taken on by synovial tissues, where activation and hyperproliferation of synovial fibroblasts leads to an inflammatory reaction. Attacking of the joints often progresses to destruction of the articular cartilage and bones, eventually resulting in ankylosis of the joints. Mainly signs and symptoms, blood tests and X-rays are used for RA diagnosis, but markers for early diagnosis or prognosis of therapy success are lacking. While various treatments are available to suppress the symptoms, disease-modifying anti-rheumatic drugs (DMARDs) are required to inhibit or halt the underlying immune process and delay or even prevent long-term damage. In the last few years, microRNAs (miRNAs) have emerged as new class of small endogenous, non-coding RNAs which regulate gene expression at the post-transcriptional level. These 22-nt long double-stranded RNAs mostly bind to target mRNAs based on partial sequence complementarity, leading to translational repression or mRNA degradation. Cumulative data indicate that proper miRNA regulation is critical for prevention of autoimmunity and normal immune functions. miRNA molecules in serum are increasingly recognized as potential biomarkers for diagnosis and prognosis in a variety of diseases.

Methods and results. If serum miRNAs are involved in response to RA treatment, we might identify a miRNA pattern that could allow estimation of e.g. the likelihood of successful treatment, i.e. to stop an unresponsive treatment as early as possible to minimize bone erosion. After establishing and optimizing serum miRNA isolation methods, the first step is the comparison of serum miRNA profiles of different untreated RA patient subgroups with that of healthy controls and osteoarthritis patients by next-generation sequencing analysis. In follow-up studies with appropriate serum RA patient samples, differentially expressed miRNAs before and after various RA treatment options will be investigated.

Conclusions. Serum miRNA profiling might allow us to gain valuable insights into the molecular role of miRNAs in the development of rheumatic diseases and allow identification of diagnostic or prognostic small RNA biomarkers and potentially of therapeutic tools for RA.

\section{5}

Differential analysis of metabolomic profiles in patients with chronic plaque psoriasis undergoing systemic treatment

\section{S. Weidinger ${ }^{7}$ \\ 'Universitätsklinikum Schleswig-Holstein, Campus Kiel, Klinik für Derma- tologie, Venerologie und Allergologie}

Background. TNF-inhibiting agents are firmly established as efficient therapy for plaque psoriasis with a highly favorable safety and tolerability profile. However, despite their common use, the therapeutic actions of these agents are not completely understood, and despite good overall clinical efficacy, a substantial proportion of the patient population fails to achieve a satisfactory clinical result. So far, the inter-individual differences in drug response cannot be predicted in patients.

Methods. Fasting serum concentrations of 200 metabolites covering a biologically relevant panel of amino acids, sugars, acylcarnitines, and phospholipids, as well as genome-wide mRNA expression profiles generated from peripheral leukocytes and skin biopsies will be analysed in patients undergoing treatment with TNF-inhibiting agents in order to identify i) biomarkers that underlie variability in response to therapy, ii) metabolomic signatures associated with psoriasis and iii) treatment-specific metabolomic signatures.

Results. Recruitment is ongoing, but recently published results from a comparable study on anti-IgE treatment in atopic dermatitis.

Conclusions. Metabolic profiling can potentially assist the classification of patients and the prediction of treatment response as well as the investigation of mechanisms of drug action. 


\section{6}

Increased Th17 cell frequency and poor clinical outcome in rheumatoid arthritis are associated with a genetic variant in the IL-4 receptor gene, rs1805010

\section{J. Leipe', M.A. Schramm?', Iryna Prots', H. Schulze-Koops', A. Skapenko' ${ }^{1} K$ linikum der Universität München, Medizinische Klinik und Poliklinik IV, Rheumaeinheit, ${ }^{2}$ Universitätsklinikum Erlangen, Interdisziplinäres Zentrum für Klinische Forschung}

Background. The minor allele of the single nucleotide polymorphism (SNP) in the IL4R gene, rs1805010, confers reduced IL-4 signaling and has previously been associated with an aggressive destructive course of rheumatoid arthritis (RA). IL-4 inhibits the development of Th17 cells, a cell population recently identified to be prominent in patients with RA and to associate with cartilage and bone destruction. Here, we investigated whether rs1805010 modulates Th17 cell development and, hence, subsequent clinical outcome in RA.

Methods. Patients with early, active RA ( $n=90$; DAS28 4.6 \pm 1.1 ) as well as controls [healthy subjects $(\mathrm{n}=24)$ and osteoarthritis patients (OA, $\mathrm{n}=15$ )] were genotyped. IL-17, IL-22 serum levels and Th17 cell frequencies were analyzed by ELISA and flow cytometry. Clinical and radiographic data were collected and evaluated at baseline and one year after disease onset.

Results. $26 \%$ patients were homozygous for the major allele of rs1805010, 60\% were heterozygous, and $14 \%$ were homozygous for the minor allele. RA patients homozygous for the minor allele demonstrated significantly higher clinical activity associated with the presence of erosions after one year of follow-up as compared to the other patients. The inhibitory effect of IL-4 on Th17 development in those patients was significantly less prominent. Accordingly, frequencies of Th17 cells and IL-17 and IL-22 serum levels were significantly increased.

Conclusions. The data indicate that the minor allele of rs1805010 contributes to the increased Th17 cell frequency, enhanced clinical activity and accelerated radiographic progression in RA by rendering $\mathrm{CD}_{4}$ T cells from RA patients insensitive to the attenuating effect of IL- 4 on Th17 cell development.

\section{7 \\ The dynamics of IgG1 and IgG4 ACPA levels during therapy in rheumatoid arthritis}

\section{R. Engelmann', C. Kneitz² , B. Müller-Hilke \\ 'Universitätsmedizin Rostock, Institut für Immunologie, ${ }^{2}$ Klinikum Südstadt Rostock, Klinik für Innere Medizin II}

Autoantibodies against citrullinated peptide antigens (ACPA) are of particular interest in rheumatoid arthritis (RA) as they substantially improved diagnosis and are indicative of immune tolerance gone astray. Recently, we could demonstrate that IgG1 and $\mathrm{IgG}_{4}$ are the most abundant immunoglobulin subclasses among two ACPA subpopulations, antibodies against cyclic citrullinated peptides (CCP) and mutated citrullinated vimentin (MCV), and that $\mathrm{IgG}_{4}$ ACPA level correlated with disease activity in two retrospectively investigated RA cohorts. In contrast, IgG1 ACPA levels were rather stable. However, there are conflicting results as to whether the levels of ACPA fluctuate with the disease status. Bos and colleagues have recently shown that IgG4 ACPA levels in RA patients decrease during treatment with tumor necrosis factor (TNF) blocking agents and that this decrease correlates with therapy response. This effect may be directly anti-TNF mediated or may be the result of an alleviated inflammatory reaction in the rheumatoid joints. In order to elucidate the mechanisms leading to a decrease in ACPA IgG4 levels we will investigate ACPA subclass titres in the course of TNF blocking as well as alternative biological or DMARD therapy. We started to collect serum samples of newly diagnosed RA patients who will be started on DMARDs and patients being started on different biologicals or changing the biological due to non-responsiveness. We will longitudinally follow up these patients at various time points to correlate ACPA levels with disease activity.

\section{8}

The impact of etanercept on retinal microcirculation and vascular dysfunction in patients with rheumatoid arthritis, psoriatic arthritis and ankylosing spondylitis

\section{T. Neumann', K. Knoll', S. Betge', C. Jung', G. Otto', G. Wolf', A. Sämann 'Universitätsklinikum Jena, Klinik für Innere Medizin III, ${ }^{2}$ Universitätsklini- kum Jena, Klinik für Innere Medizin I}

Background. Increased mortality in chronic rheumatic diseases is mostly attributed to cardiovascular events (CVE). Assessment of endothelial dysfunction can help to identify patients at risk for major CVE. Studies have shown that the underlying endothelial dysfunction in rheumatoid arthritis is closely associated with inflammation. Only limited information is available whether the blockade of TNFa can restore endothelial function and decrease the incidence of cardiovascular events.

Methods. Patients with active rheumatoid arthritis (RA), psoriatic arthritis (PsA) and ankylosing spondylitis (SpA) were eligible for inclusion when anti-TNF-treatment was started. Study visits were performed at baseline, after one and three months. Clinical disease activity and inflammation marker were obtained. Systemic Coronary Risc Evaluation (SCORE) and measurement of intima media thickness (IMT) were performed to assess baseline cardiovascular (CV) risk. Endothelial function was measured by retinal vessel analysis (RVA) and peripheral tonometry (EndoPAT). Serum levels of pentraxin-3 were analysed as marker of endothelial function.

Results. At this point 26 patients (11 RA, 6 PsA, 9 SpA) were analysed. Treatment was initiated with etanercept, certolizumab, infliximab, adalimumab or golimumab. Response to treatment after 3 month measured by ACR50 (RA and PsA) and ASAS2o (SpA) was found in $35 \%$ of RA-, $80 \%$ of PsA- and $63 \%$ of SpA patients. At baseline $7.7 \%$ $(n=2)$ of patients had a risk for CV events $>5 \%$. IMT was $<0.9 \mathrm{~mm}$ in all patients. Reactive hyperaemia index (RHI) assessed by EndoPAT was $1.87 \pm 0.49$ (normal $>1.67$ ). RVA showed differences of $-0.03 \%$ (dilatation), $-3.5 \%$ (constriction) and $-2.1 \%$ (amplitude) compared to published data from age matched healthy individuals. One month after initiation of anti-TNF-treatment the increase in RHI was significantly higher in patients who did respond to treatment compared with nonresponders. RVA measurements did not reveal differences between responders and non-responders. Finally, serum levels of pentraxin-3 at baseline were $0.64 \pm 0.41 \mathrm{ng} / \mathrm{ml}$ (normal $<0.65 \mathrm{ng} / \mathrm{ml}$ ). A greater decrease of pentraxin-3 was observed in responders compared with nonresponders after one month, but did not reach the level of significance $(\mathrm{p}<0.05)$

Conclusions. Our data indicate that patients with active RA, PsA or $\mathrm{SpA}$ are at risk for cardiovascular events. Both, RVA and EndoPAT measurements indicate a greater risk in certain patients at baseline. After initiation of anti-TNF-treatment, responders show improvement of RHI in EndoPAT but no change in RVA. Overall, the data need to be interpreted with caution due to the relatively small number of investigated patients. 


\section{Abstracts without presentation}

\section{1}

The role of gut microbiota in rheumatoid arthritis and its modulation by anti TNFa agents - implications for the predicition of therapy response?

\section{K. Aden', R. Zeuner', S. Schreiber', P. Rosenstiel', J.-O. Schröder ${ }^{3}$ 'Christian-Albrechts-Universität zu Kiel, Institut für Klinische Moleku- larbiologie, ${ }^{2}$ Universitätsklinikum Schleswig-Holstein, Klinik für Innere Medizin I, ${ }^{3}$ Exzellenzzentrum Entzündungsmedizin UKSH - Campus Kiel}

Background. Rheumatoid arthritis (RA) is a chronic disease of unknown aetiology that affects primarily the peripheral joints. Characteristic features of RA pathogenesis are synovial inflammation and proliferation accompanied by cartilage erosion and bone loss, leading to functional disability. Although the pathophysiological mechanisms are not fully understood, successful therapeutic intervention by antiTNF agents indicates a decisive role of disturbed cytokine homeostasis in the development of RA. Anti-TNF agents have been the mainstay in the treatment of severe RA, which is refractory to conventional immunosuppressive treatment. Nevertheless the therapeutic options are limited by the fact that approximately one-third of patients are non-responsive to anti-TNF agents due to lack of drug efficacy or due to establishing adverse events. These data underline, that the understanding of mechanisms leading to primary and secondary loss of function are the key questions of further research in the RA field. Recent initial studies underline the hypothesis of intestinal dysbiosis in rheumatoid arthritis by showing that different fecal lactobacillus community structures are strongly associated with disease activity in rheumatoid arthritis. This study is designed to assess the role of intestinal gut microbiota in rheumatoid arthritis.

Methods. Patients, aged 18-80 years, male and female, with diagnosis of active rheumatoid arthritis [defined as Disease Activity Score in 28 joints $(\mathrm{DAS} 28)>4$ despite previous therapy with at least 2 DMARDS, one of which should be MTX] or diagnosed with osteoarthritis (healthy control) will be eligible for this study. Stool and blood samples will be collected from patients receiving MTX $(n=20)$ or anti-TNF agents (Adalimumab, Etanercept; $n=20$ each) at various time points before and after drug-administration. For analysis of the intestinal microbiota microbial DNA will be isolated and 16s rRNA will be subjected to 454-pyrosequencing and further analysis as described before. In short, intestinal microbiota will be analyzed according to microbial richness and abundance according (i) intraindividual time dependent changes after treatment and (ii) interindividual changes according to treatment groups.

Results. Results are expected to give rise to the questions whether intestinal dysbiosis is present in patients with rheumatoid arthritis, therapeutic cytokine neutralization by anti TNF-agents shapes the gut microbiota, the impact of therapeutic cytokine neutralization by anti TNF-agents on gut microbiota correlates with response/non-response in rheumatoid arthritis? These data could generate insights into the role of dysbiosis in rheumatoid arthritis and the role of gut microbial determinants that predict therapy response in chronic inflammatory disorders in general.

\section{2}

Comparison of risk and patient-related benefit of treatment with etanercept in elderly patients with rheumatoid arthritis (acronym: CORELA)

\section{P. Klaus', A. Pfadenhauer', V. Köhler', G.R. Burmester', J. Detert' \\ 'Charité - Universitätsmedizin Berlin, Med. Klinik m. S. Rheumatologie und Klinische Immunologie}

Background. Initial manifestation of rheumatoid arthritis (RA) is after the age of 60 years in one third of patients. The TNF- $\alpha$ inhibitor etanercept (ETA) has been shown to significantly reduce disease activity in RA patients not responding to treatment with traditional disease-modifying anti-rheumatic drugs (DMARD) and to enhance the functional capacity after inhibition of inflammation. However, little is known about the influence on patient-reported outcomes such as quality of life and fatigue in elderly patients due to the fact that patients in phase-III studies are usually younger. Furthermore, there is only limited data whether treatment with immunomodulatory drugs leads to a higher rate of therapy-related adverse events in elderly patients. The aim of this non-interventional observation study is to evaluate the effect of ETA on quality of life, fatigue, and quality of sleep in elderly patients, and to compare the results with clinical disease activity determined by DAS 28 , as well as safety parameters [adverse events (AE) and serious AE].

Methods. There are two study groups: 1. patients beginning with ETA and/or DMARD, and 2. patients beginning with only DMARD therapy. The study duration per patient is one year: screening and baseline visit, visit 1 after 6 months (T1), and visit 2 after 12 months (T2). According to the sample size calculation, 65 patients per group are needed (130 patients in total). Main inclusion criteria: 1. patients older than 60 years, 2. RA according to ACR criteria from 1987, 3. treatment with ETA and/or DMARD, as indicated according to DGRh. The primary endpoint of this study is the long-term effect of ETA on quality of life, fatigue, and quality of sleep assessed by validated questionnaires after $\mathrm{V}_{1}$ and $\mathrm{V}_{2}$. Secondary end points are (all from To to $\mathrm{T}_{1}$ and $\mathrm{T}_{2}$ ) 1. change in disease activity by DAS 28 and CDAI, 2 . functional capacity (HAQ), 3. pain, 4. eating behaviour, 5. emotional state, 6. ACR2O, ACR50, ACR70. Safety aspects are assessed as AE and SAE from To to $\mathrm{T} 1$ and $\mathrm{T} 2 \mathrm{using}$ a patient diary.

Results. 31 study sites across Germany participate in this project. $\mathrm{Pa}$ tient recruitment started in July 2012. So far, 22 patients have been included in the study, 10 in the ETA group, and 12 in the DMARD group. Recruitment is still ongoing to meet the goal of 65 patients per group. Registration of new study sites is still possible.

Conclusions. This study aims at evaluating the effect of ETA on quality of life, fatigue, and quality of sleep in elderly patients. Recruitment is still ongoing; to meet the goal of 130 patients, only three more patients per study site need to be recruited. 


\section{Autorenregister}

\section{Authors}

A

Aden K.

5.1

\section{B}

Barvencik F. $\quad 1.4$

Becker $\mathrm{H}$. $\quad 4.3$

Behrens F. $\quad 1.2,4.2$

Bertrand J. $\quad 1.4$

Betge S. $\quad 4.8$

Böhm B. $\quad 1.2$

Buchbender C. $\quad 2.1$

Burkhardt H. $\quad 1.2,4.2$

Burmester G.R. $\quad 5.2$

\section{c}

Callhoff J. $\quad 3.1$

Carbone T. $\quad 1.3$

Cavani A. $\quad 1.3$

Cromme C. $\quad 1.4$

D

Dankbar B. $\quad 1.4$

Detert J. $\quad 5.2$

Dietrich A. $\quad 1.4$

Dobrindt U. $\quad 1.1$

Drynda S. $\quad 4.1$

E

Ebbinghaus S. $\quad 2.2$

Engelmann R. $\quad 4.7$

F

Fassbinder T. $\quad 4.3$

Finzel S. $\quad 2.5$

Frank S. $\quad 1.4$

\section{G}

Greene B.H. $\quad 1.3$

Gruenke M. 2.3

H

Haas J.P. $\quad 3.2$

Harrach S. $\quad 1.4$

Hartmann M. $\quad 3.2$

Hertl M. $\quad 1.3$

Hidding $\mathrm{H}$. $\quad 1.4$

Horneff G. $\quad 3.3$

\section{J}

Jäck H.M. $\quad 4.4$

Jacobi A. $\quad 1.3$

Jacobi A.M. $\quad 4.3$

Jung C. $\quad 4.8$

Jung $E$. $\quad 4.3$

K

Kekow J. $\quad 4.1$

Klaus $P$. $\quad 5.2$

Kleyer A. $\quad 2.5$

Kneitz C. $\quad 4.7$

Knoll K. $\quad 4.8$

Köhler V. $\quad 5.2$

Köhm M. $\quad 1.2,4.2$

Kornak U. $\quad 1.4$

Kreuzpointner F. $\quad 3.2$

L

Langhans B. $\quad 2.3$

Leipe J. $\quad 4.6$

Lindeman $0 . \quad 1.4$

Loser K. $\quad 1.1$

Luger T.A. $\quad 1.1$

M

Marshall R.P. $\quad 1.4$

Matthes-György K. $\quad 2.1$

Mickholz E. $\quad 4.3$

Miese F. $\quad 2.1$

Möbs C. $\quad 1.3$

Moll R. $\quad 1.3$

Müller-Hilke B. $\quad 4.7$

$\mathrm{N}$

Neumann T.

4.8

0

Oleszowsky M. $\quad 2.2$

Ostendorf B. $\quad 2.1$

Otto G.

4.8

$P$

Pap T.

1.4

Pfadenhauer A. $\quad 5.2$

Prots I.
R

Rech J. $\quad 2.4,2.5$

Rosenstiel P. $\quad 5.1$

Roßmanith T. $\quad 4.2$

$S$

Saam T. $\quad 2.3$

Sämann A. $\quad 4.8$

Saunders U. $\quad 4.3$

Scherer A. $\quad 2.1$

Schett G. $\quad 2.5$

Schlüter B. $\quad 4.3$

Schneider M. $\quad 2.1,3.1$

Schramm M.A. $\quad 4.6$

Schreiber S. $\quad 5.1$

Schröder J.-O. $\quad 5.1$

Schulze-Koops $\mathrm{H} . \quad 2.3,4.6$

Schwab A. $\quad 1.4$

Schwirtz A. $\quad 3.2$

Seidel M.F. $\quad 2.2$

Sesselmann S. $\quad 4.4$

Sewerin P. $\quad 2.1$

Skapenko A. $\quad 4.6$

Stange R. $\quad 1.4$

Steiner M. $\quad 1.4$

U

Umlauf D. $\quad 1.4$

W

Weidinger $\mathrm{S}$. $\quad 4.5$

Westhoff G. $\quad 3.1$

Wieskoetter B. $\quad 1.4$

Willeke P. $\quad 4.3$

Willinek W. $\quad 2.2$

Witt M. $\quad 2.3$

Wittmann J. $\quad 4.4$

Wittsack H.-J. $\quad 2.1$

Wohlrab J. $\quad 3.4$

Wolf G. $\quad 4.8$

Z

Zeuner R. $\quad 5.1$

Zink A. $\quad 3.1$ 
Zusammensetzung: Enbrel 10 mg, $-\mathbf{2 5}$ mg: 1 Durchstechfl. m. Plv. enth.: 10 mg bzw. 25 mg Etanercept. Sonst. Bestandt.: Pulver: Mannitol, Sucrose, Trometamol. 1 Fertigspritze m. Lsg.-mittel enth. Wasser f. Inj.-Zwecke. Enbrel $25 \mathrm{mg} /-$ $50 \mathrm{mg}$ Inj.-Lsg. in Fertigspr. u. Enbrel $50 \mathrm{mg}$ Inj.-Lsg. im Fertigpen (MYCLIC): 1 Fertigspr. enth.: Etanercept 25 mg bzw. 50 mg, 1 Fertigpen enth. Etanercept $50 \mathrm{mg}$. Sonst. Bestandt.: Sucrose, Natriumchlorid, Argininhydrochlorid, Natriumdihydrogenphosphat-Dihydrat, Natriummonohydrogenphosphat-Dihydrat, Wasser f. Inj.-Zwecke. Etanercept wird gentechn. aus der Eierstockzelllinie d. Chinesischen Hamsters hergestellt. Anwendungsgebiete: Enbrel $25 \mathrm{mg} \mathrm{u}$. 50 mg: Rheumatoide Arthritis: Enbrel ist in Komb. m. Methotrexat (MTX) zur Behandl. d. mittelschweren bis schweren aktiven rheumatoiden Arthritis (RA) bei Erw. indiziert, wenn Ansprechen auf Basistherapeutika (einschl. MTX - sofern nicht kontraind.) unzureichend ist. Enbrel kann im Falle einer Unverträglichk. gegenüber MTX od. wenn eine Forts. d. Behandl. m. MTX nicht mögl. ist, als Monother. angewendet werden. Behandl. der schweren, aktiven u. progressiven rheumatoiden Arthritis bei Erw., die zuvor nicht m. MTX behandelt worden sind. Enbrel reduziert als Monother. od. in Komb. m. MTX d. Fortschreiten d. radiolog. nachweisbaren strukturellen Gelenkschädig. u. verbessert d. körperl. Funktionsfähigk. Psoriasis-Arthritis (Arthritis psoriatica): Behandl. d. aktiven u. progressiven Psoriasis-Arthritis bei Erw., wenn Ansprechen auf vorhergehende Basisther. unzureichend ist. Enbrel verbessert d. körperl. Funktionsfähigk. bei Pat. m. Psoriasis-Arthritis u. reduziert d. Fortschreiten d. radiolog. nachweisbaren strukturellen Schädig. peripherer Gelenke b. Pat. m. polyartikulären symmetrischen Subtypen d. Erkrank. Morbus Bechterew (Spondylitis ankylosans): Behandl. d. schweren aktiven Morbus Bechterew bei Erw., die unzureichend auf konventionelle Behandl. angesprochen haben. Plaque-Psoriasis: Behandl. Erwachsener m. mittelschwerer bis schwerer Plaque-Psoriasis, die auf eine andere syst. Ther. wie Ciclosporin, MTX od. Psoralen u. UVA-Licht (PUVA) nicht angesprochen haben od. bei denen eine Kontraind. od. Unverträglichk. einer solchen Ther. vorliegt. Enbrel $10 \mathrm{mg}$ sowie zusätzl. f. Enbrel 25 mg u. $\mathbf{5 0}$ mg: Juvenile idiopathische Arthritis (JIA): Behandl. d. Polyarthritis (Rheumafaktor-positiv od. -negativ) u. d. erweiterten (extended) Oligoarthritis bei Kindern u. Jugendl. ab $2 \mathrm{~J}$., die unzureichend auf MTX-Behandl. angesprochen haben od. MTX-Behandl. nicht vertragen. Behandl. d. Psoriasis-Arthritis (Arthritis psoriatica) bei Jugendl. ab $12 \mathrm{~J}$., die unzureichend auf MTX-Behandl. angesprochen haben od. MTX-Behandl. nicht vertragen. Behandl. d. Enthesitis-assoziierten Arthritis bei Jugendl. ab 12 J., die unzureichend auf eine konventionelle Ther. angesprochen haben od. eine konventionelle Ther. nicht vertragen. Plaque-Psoriasis bei Kindern u. Jugendl.: Behandl. d. chron. schweren Plaque-Psoriasis bei Kindern u. Jugendl. ab $6 \mathrm{~J}$., die unzureichend auf eine and. system. Ther. od. Lichtther. angesprochen haben od. sie nicht vertragen. Gegenanzeigen: Überempfindlichk. gegen den Wirkstoff od. einen d. sonst. Bestandteile. Nicht anw. bei Sepsis od. Risiko einer Sepsis (cave: mögl. Erhöhung d. Mortalität bei bestehender Sepsis). Ther.-Beginn nicht bei aktiven Infekt., einschl. chron. od. lokalisierter Infekt. od. bei Pat. m. aktiver Tuberkulose. Pat. m. inaktiver Tuberkulose nur nach entspr. Anti-Tuberkulose-Ther. u. sehr sorgf. Nutzen/Risiko-Abwägung. Warnhinweise und Vorsichtsmaßnahmen: Pat. vor, währ. u. nach Enbrel-Behandl. auf Infekt. hin untersuchen. Vorsicht walten lassen bei Pat. m. wiederkehrenden od. chron. Infekt. i. d. Vorgeschichte od. m. Begleiterkrank., die Infekt. begünstigen können (z. B. fortgeschrittener oder schlecht eingestellter Diabetes), sowie bei neuentwickelten Infekt. Unter Anw. v. Enbrel wurden schwerw. Infekt., Sepsis, Tuberkulose (Tb) u. opportunistische Infekt., einschl. invasiver Pilzinfekt., Listeriose u. Legionellose beobachtet (in einigen Fällen $\mathrm{m}$. Todesfolge durch Nichterkennung u. verzögerte Behandl.). Pat.-Risiko für relevante opportunist. Infekt. berücksichtigen. Therabbruch bei Entwickl. v. schwerer Infekt., sowie bei Auftreten schwerw. allerg. od. anaphylakt. Reakt. Vor Behandlungsbeginn alle Pat. auf aktive u. inaktive (latente) Tb hin untersuchen. Pat. anweisen, bei Tb-Sympt. ärztl. Rat einzuholen. Reaktivierung d. Hepatitis B Erkrank. wurde bei Pat. berichtet, die zuvor mit HBV infiz. waren u. gleichz. TNF Antagonisten, einschl. Enbrel, erhielten. Pat. $m$. posit. HBV-Test sollten währ. d. Ther. u. mehrere Wochen danach auf Sympt. einer aktiven HBV Infekt. hin überw. werden. Wenn eine HBV-Infektion auftritt, sollte Enbrel abgesetzt u. eine antivirale Ther. mit geeign. unterstütz. Behandl. eingeleitet werden. Besondere Vors. bei Pat. m. Blutdyskrasie in d. Anamnese, bei Auftreten v. Sympt. eindringl. Abklärung; bei nachweisl. Blutdyskrasie Enbrel absetzen. Bei starker Exposition gegenüber Varizella-Viren Behandl. vorübergehend abbrechen, ggf. Prophylaxe $\mathrm{m}$. Varizella-zoster-Immunglobulinen. Regelm. Hautuntersuch. empf., da unter Behandl. m. TNF-Antagonisten, einschl. Enbrel, über Melanome und nicht-melanozytären Hautkrebs (NMSC) berichtet wurde. Besondere Vors. bei Pat. m. Herzinsuffizienz; Pat. m. Hepatitis C i.d. Anamnese wg. mögl. Verschlecht.; Enbrel nicht zur Behandl. v. AlkoholHepatitis anw.; Vorsicht b. Pat., die auch an mittelschw. bis schwerer Alkohol-
Hepatitis leiden. Komb. Anw. v. Enbrel m. Anakinra oder Abatacept sowie Anw. v. Enbrel bei Wegener'schen Granulomatose wird nicht empf..; bei gleichz. medikamentöser Diabetes-Behandl. Fälle v. Hypoglykämie (ggf. Dosisred. v. Antidiabetika notw.); Vorsicht b. älteren Pat., insb. auf mögl. Infekt. achten. Keine gesicherten Erkenntnisse über Langzeitsicherheit v. Enbrel bei gleichzeitiger Gabe m. anderen antirheumatischen Basistherapeutika (DMARD). Anw. in Schwangerschaft u. Stillzeit nicht empf. Mögl. Risiko f. die Entwickl. v. Lymphomen, Leukämie od. and. hämatopoetischen malignen Erkrank. od. soliden Tumoren kann derzeit bei Ther. m. TNF-Antagonisten nicht ausgeschlossen werden; deshalb Behandl. abwägen bei Pat. m. maligner Erkrank. i.d. Anamnese od. Entwickl. v. maligner Erkrank.; Sicherheit u. Wirksamk. v. Enbrel bei Pat. m. Immunsuppression od. chron. Infekt. wurden bisher nicht untersucht. Lebendimpfstoffe sollten nicht gleichzeitig verabreicht werden. Sorgf. Nutzen-Risiko-Analyse, einschl. neurolog. Untersuchung, bei bestehender od. jüngst neu aufgetretener Entmarkungskrankheit od. evtl. erhöhtem Risiko f. Entwickl. einer Entmarkungskrankheit. Anw. v. Enbrel in Komb. m. anderen syst. Ther. od. Lichtther. zur Behandl. v. Psoriasis wurde nicht untersucht. Nur für Enbrel $25 \mathrm{mg} / 50 \mathrm{mg}$ Fertigspritze u. Enbrel $50 \mathrm{mg}$ Fertigpen: Kanülenkappe d. Fertigspritze bzw. d. Fertigpens enth. Latex (Trockenkautschuk), das Überempfindlichkeitsreakt. verursachen kann. Nebenwirkungen: Basierend auf Beobachtungen aus klin. Studien bei Erw. u. Berichten n. Markteinf.: Sehr häufig: Reakt. an d. Inj.-stelle, ggf. passagere "Recall“-Reakt. an d. Inj.-stelle, Infekt. (einschl. Infekt. d. oberen Atemwege, Bronchitis, Zystitis, Hautinfekt.). Häufig: Allerg. Reakt., Fieber, Bildung v. Autoantikörpern, Pruritus. Gelegentl.: Schwere Infekt. (einschl. Pneumonie, Erysipel, sept. Arthritis, Sepsis, parasitäre Infekt.), nicht-melanozytärer Hautkrebs, Thrombozytopenie, systemische Vaskulitis, Uveitis, Skleritis, interstitielle Lungenerkrank. (einschl. pulmonale Fibrose u. Pneumonitis, z.T. letal), Angioödem, Urtikaria, Hautausschlag, psoriasisartiger Hautausschlag, Psoriasis (einschl. Erstmanifestationen od. Verschlecht. u. pustulöse Formen, primär Handflächen u. Fußsohlen). Selten: Tuberkulose (inkl. Miliartuberkulose u. extrapulmonärer Tuberkulose), opportunist. Infekt. (einschl. invasive Pilz-, Protozoen-, Bakterien-, u. atypische Mycobakterien-Infekt. u. Legionellose), Lymphom, Melanom, Anämie, Leukozytopenie, Neutropenie, Panzytopenie, schwere allerg./anaphylakt. Reakt. (einschl. Angioödem, Bronchospasmus), Sarkoidose, Anfälle, ZNS-entmyelinisierende Ereign. $\mathrm{m}$. Verdacht auf multiple Sklerose od. lokalisierte entmyelinisierende Zustände wie Neuritis nervi optici u. Querschnittsmyelitis; Verschlecht. v. Herzinsuff., erhöhte Leberenzyme, autoimmune Hepatitis, kutane Vaskulitis (einschl. leukozytoklastische Vaskulitis), Stevens-Johnson-Syndrom, Erythema multiforme, subakuter kutaner od. diskoider Lupus erythematodes, Lupus-ähnl. Syndrom, entmyelinisierende Erkrank. d. ZNS. Sehr selten: Aplastische Anämie, toxische epidermale Nekrolyse, periphere demyelinisierende Ereignisse (einschl. Guillain-Barré-Syndr., chron.-entzündl. demyelinisierende Polyneuropathie, demyelinisierende Polyneuropathie u. multifokale motorische Neuropathie). Häufigkeit nicht bekannt: Listeriose, Hepatitis B-Virus-Reaktivierung, Leukämie, Merkelzell-Karzinom, Makrophagen-Aktivierungs-Syndrom, Verschlecht. einer Dermatomyositis. In Studien zur RA m. (Dauer bis zu 48 Mon.) wurden schwerw. Infekt. beobachtet einschl.: Abszess, Bakteriämie, Bronchitis, Bursitis, Erysipel, Cholezystitis, Diarrhoe, Divertikulitis, Endokarditis (vermutet), Gastroenteritis, Hepatitis B (Reaktivierung b. chron. HBV-Trägern), Herpes zoster, Unterschenkelgeschwür, Mundinfekt., Osteomyelitis, Otitis, Peritonitis, Pneumonie, Pyelonephritis, Sepsis, septische Arthritis, Sinusitis, Hautinfekt., Hautgeschwür, Harnwegsinfekt., Vaskulitis, Wundinfekt.; Nach Markteinf. wurde über versch. Malignome (einschl. Brust- u. Lungenkarzinom sowie Lymphom) berichtet. Bei Komb. v. Enbrel m. MTX (Studie): Raten d. schwerw. Infekt. waren gegenüber d. Monother. ähnl., jedoch ist ein Anstieg d. Infektionsrate bei Kombi-Therapie mögl. In Studien zur Plaque-Psoriasis: Schwere Infekt. wie Erysipel, Gastroenteritis, Pneumonie, Cholezystitis, Osteomyelitis, Gastritis, Appendizitis, Streptokokken-Fasziitis, Myositis, sept. Schock, Divertikulitis u. Abszess. Bei gleichz. Anw. v. Enbrel u. Anakinra wurde bei erw. Pat. ein erhöhtes Risiko f. schwerw. Infekt. u. Neutropenie beobachtet. Nebenwirk. bei Kdrn. u. Jugendl.: Diese waren i. A. denen d. Erw. ähnl. Nebenwirk. bei Kdrn. u. Jugendl. m. JIA: Häufiger als bei Erw. waren: Kopfschmerzen, Übelkeit, Erbrechen u. Unterleibsschmerzen. Es gab Berichte über chron.-entzündl. Darmerkrank.; Schwerw. NW umfassten: Varizellen-Infektion m. Zeichen u. Sympt. v. aseptischer Meningitis (ohne Folgeschäden), Blinddarmentz., Gastroenteritis, Depression/Persönlichkeitsstör., Hautgeschwür, Ösophagitis, Gastritis, sept. Schock, Typ I Diabetes mellitus, Weichteil $\neg$ infekt. u. postoperative Wundinfekt. Weitere Informationen siehe Fach- u. Gebrauchsinformation. Abgabestatus: Verschreibungspflichtig. Inhaber der Zulassung: Pfizer Limited, Ramsgate Road, Sandwich, Kent CT13 9 $\mathrm{NJ}$, Vereinigtes Königreich. Repräsentant in Deutschland: PFIZER PHARMA $\mathrm{GmbH}, 10785$ Berlin. Stand: Oktober 2013 
